\title{
Diagnosis and Classification of Malignant Lymphoma and Related Entities in the Bone Marrow Trephine Biopsy
}

\author{
Falko Fend Markus Kremer \\ Institute of Pathology, Technical University Munich, Munich, Germany
}

\author{
Key Words \\ Bone marrow $\cdot$ Immunohistochemistry $\cdot$ Molecular \\ pathology
}

\begin{abstract}
The trephine bone marrow (BM) biopsy is an important diagnostic tool in patients with malignant lymphoma. BM examination can serve to establish or confirm a primary diagnosis of lymphoma or to determine the extent of disease dissemination for staging purposes. BM histology renders information which cannot be gained equally from aspirate material, such as spacial distribution and extent of infiltrates, BM cellularity and fibrosis. Furthermore, cytology including flow cytometric immunophenotyping can give false-negative results in BM involvement by lymphoma due to intralesional fibrosis. In addition to morphological examination, the availability of a broad panel of antibodies suitable for paraffin-embedded tissues, in conjunction with less damaging decalcification procedures, nowadays enables us to perform complete immunophenotyping on BM trephines and allows for classification of lymphoma infiltrates according to established algorithms. Molecular determination of clonality and interphase fluorescent in situ hybridization can be
\end{abstract}

This work was supported in part by DFG Grant FE597/1-2 to F.F. and M.K.
(C) 2007 S. Karger AG, Basel

1015-2008/07/0742-0133\$23.50/0

Fax +4161306 1234

E-Mail karger@karger.ch

www.karger.com
Accessible online at:

www.karger.com/pat employed selectively to resolve difficult cases. This review describes important diagnostic features of malignant lymphoma in the BM, relevant differential diagnoses, and the proper use of ancillary techniques.

Copyright $\odot 2007$ S. Karger AG, Basel

\section{Introduction}

The trephine bone marrow (BM) biopsy is an integral part of the diagnostic work-up of patients with a diagnosis of malignant lymphoma [1-7]. In most instances, BM biopsy is performed for staging or follow-up purposes, but in a significant minority of cases, BM examination serves as a means for primary diagnosis, especially in disseminated low-grade B-cell non-Hodgkin's lymphoma (B-NHL). The absence or presence of BM infiltration has a significant impact on prognosis and treatment options in a variety of NHL and Hodgkin's disease.

In lymphoma patients, the trephine biopsy renders important diagnostic information which cannot be obtained from BM aspirates, namely on architectural features of the infiltrate and its topographic distribution as well as the amount of marrow space occupied by a malignant infiltrate $[4,6,7]$. Furthermore, assessment of marrow involvement by histology is not impeded by fibrosis, which is a frequent finding in lymphomatous infiltrates and may lead to false-negative results in BM aspirates due 
to sampling error [8-10]. For these reasons, the performance of a unilateral (or bilateral) BM trephine of adequate size with a minimal length of $2 \mathrm{~cm}$, preferably examined by step sectioning, is regarded mandatory in patients with malignant lymphoma both for the initial determination of BM involvement and response evaluation $[11,12]$. However, trephine biopsy, aspiration cytology and flow cytometric immunophenotyping should be seen as integral parts of a combined approach ideally resulting in a joint diagnostic assessment $[1,3]$.

The development of a broad range of antibodies suitable for paraffin-embedded tissues, in conjunction with decalcification techniques, which are non-detrimental for most relevant antigens, has increased the diagnostic value of the BM biopsy further and has made it complementary, and in many instances superior to flow cytometric immunophenotyping of $\mathrm{BM}$ aspirates $[6,7,13]$. The present review gives an overview of the practical issues in the diagnostic evaluation of BM trephines in patients with malignant lymphoma and related disorders and critically reviews the role of ancillary techniques.

\section{Frequency and Patterns of BM Infiltration in Malignant Lymphoma}

The frequency of BM infiltration varies widely for different subtypes of malignant lymphoma and ranges from $5 \%$ in Hodgkin's lymphoma $[14,15]$ to almost $100 \%$ for patients with small lymphocytic B-cell lymphoma/chronic lymphocytic leukemia [1]. BM infiltration by malignant lymphoma is not a random process but is influenced by characteristics of the neoplastic cells as well as microenvironmetal features, leading to a characteristic pattern of marrow involvement for many lymphoma subtypes [ 4 , $6,7,13]$. These infiltration patterns, though not absolutely specific, may provide diagnostic clues both for the discrimination of benign and malignant infiltrates as well as for NHL subtyping. Five major patterns of BM infiltration can be discerned, namely a nodular intertrabecular, a nodular paratrabecular, an interstitial, a diffuse and an intrasinusoidal pattern. However, patterns can change during the course of the disease, and mixed patterns occur frequently. For neoplasms such as B-CLL, not only the presence, but the amount as well as the distribution of BM infiltrates are of clinical relevance, although the independent prognostic significance of BM pattern in BCLL has recently been challenged [16-18].

The differential diagnosis of various lymphoma subtypes in the BM is based on a combination of architec- tural and cytological features, complemented by immunohistochemistry. Whereas most lymphomatous BM infiltrates are readily identifiable by morphology, early interstitial infiltrates and the intrasinusoidal pattern may easily by overlooked in standard histological stains and require immunohistochemistry for their detection [1921]. The following summarizes important diagnostic features of major lymphoma subtypes.

\section{Hodgkin's Lymphoma}

BM infiltration is rare both in classical Hodgkin's lymphoma as well as in lymphocyte-predominant Hodgkin's lymphoma (nodular paragranuloma), occurring in less than $5 \%$ in most large clinical series $[14,15]$. For these reasons, some authors have advocated to forgo BM examination in patients lacking clinical risk factors such as B symptoms and involvement on both sides of the diaphragm. In contrast to Hodgkin's lymphoma in immunocompetent patients, BM involvement in patients with HIV infection is found in $25-50 \%$ of cases, and a BM trephine may be the site of primary diagnosis [22-24].

BM infiltration by Hodgkin's lymphoma is characterized by randomly distributed infiltrates consisting of a mixture of small lymphocytes, plasma cells, histiocytes and eosinophils and rare atypical cells, usually accompanied by significant fibrosis and occasional epithelioid cell granulomas [1]. In patients with a confirmed diagnosis of Hodgkin's lymphoma at another site, the presence of such infiltrates is considered compatible with a diagnosis of $\mathrm{BM}$ involvement even in the absence of diagnostic ReedSternberg cells. Immunohistochemistry for CD30 and, with limitations due to the presence of granulocytes, CD15 is very helpful in confirming suspected BM infiltrates of classical Hodgkin's lymphoma (fig. 1G). Infiltrates of some NHL subtypes, mainly peripheral T-cell lymphoma NOS and angioimmunoblastic T-cell lymphoma may simulate Hodgkin's lymphoma in the BM and require either a lymph node biopsy or extensive immunophenotyping for a definitive diagnosis.

\section{Non-Hodgkin's Lymphoma}

\section{Small B-Cell NHL}

The small B-cell NHL including B-CLL/SLL, lymphoplasmacytic lymphoma (LPL), follicular lymphoma (FL), mantle cell lymphoma (MCL), marginal zone B-cell lymphomas and hairy cell leukemia (HCL) frequently involve 
Table 1. Differential diagnosis of small B-NHL

\begin{tabular}{|c|c|c|c|c|c|c|c|}
\hline Diagnosis & $\begin{array}{l}\text { Common } \\
\text { infiltration patterns }\end{array}$ & $\mathrm{CD} 20$ & CD5 & CD23 & $\begin{array}{l}\text { Cyclin } \\
\text { D1 }\end{array}$ & $\begin{array}{l}\text { Additional } \\
\text { markers }\end{array}$ & Comments \\
\hline B-CLL & nod/i, int, diffuse & $+(w)$ & + & + & - & CD43+, ZAP70+/- & occasional proliferation centers \\
\hline MCL & $\operatorname{nod} / \mathrm{p}+\mathrm{i}$; int & + & + & - & + & CD43+, p27- & \\
\hline MZL & $\operatorname{nod} / \mathrm{i}$ & + & - & - & - & CD43-1+ & occasional reactive GC \\
\hline LPL & $\operatorname{nod} / \mathrm{i}$ & + & $-/+$ & - & - & $\mathrm{cIg}+$ & mast cell hyperplasia \\
\hline HCL & int, diffuse & + & - & - & $+/-$ & $\begin{array}{l}\text { DBA44+, CD25+, TRAP }+ \text {, } \\
\text { CD11c+, Annexin A1+ }\end{array}$ & loose infiltrate, fibrosis \\
\hline MM & random & $-/(+)$ & - & - & $-1+$ & $\begin{array}{l}\text { Ig light chains, CD138+, } \\
\text { CD } 38+, \text { VS38c+, CD } 56+/-\end{array}$ & \\
\hline
\end{tabular}

MCL = Mantle cell lymphoma; MZL = marginal cell lymphoma; LPL = lymphoplasmacytic lymphoma; SMZL = splenic MZL; $\mathrm{FL}=$ follicular lymphoma; $\mathrm{HCL}=$ hairy cell leukemia; $\mathrm{MM}=$ multiple myeloma; nod $/ \mathrm{i}=$ nodular intertrabecular; nod $/ \mathrm{p}=\mathrm{nodular}$ paratrabecular; int = interstitial; $\sin =$ sinusoidal; $\mathrm{w}=$ weak.

the BM and make up for a large percentage of BM infiltrates in patients with malignant lymphoma $[2,4,6,7$, 13]. The diagnostic criteria for the different small B-cell lymphoma entities are summarized in table 1.

$B-C L L / S L L$ is the most common indolent B-NHL in higher age groups and shows a broad range of clinical behaviors. BM involvement is present in virtually all cases. Infiltrates may be intertrabecular nodular, interstitial or diffuse, with the latter pattern representing a more advanced disease and found more frequently in patients with higher stage according to Rai or Binet [16-18, 25]. Significant intralesional fibrosis or predominantly paratrabecular infiltrates are unusual and should prompt immunohistochemical studies to confirm the diagnosis. Proliferation centers are found in the BM at lower frequency than in lymph nodes, but can be observed in some patients with predominantly nodular infiltrates. Large proliferation centers may contain significant numbers of paraimmunoblasts, which has to be discerned from large cell transformation (Richter's transformation) of B-CLL. Richter's transformation in the BM is infrequent and is associated with diffuse sheets of large cells with high proliferation rate, frequent overexpression of $\mathrm{p} 53$ protein and occasional BM necrosis.

Immunohistochemical examination is very useful to confirm the characteristic immunophenotype of B-CLL with coexpression of CD23 and CD5 and lack of cyclin $\mathrm{D} 1$, and to distinguish it from other small B-cell lymphomas, especially MCL $[26,27]$. Of note, CD20 expression can be very weak to absent in B-CLL [28]. ZAP-70 protein, a strong prognostic marker in B-CLL highly, but not invariably associated with unmutated immunoglobulin variable genes $[29,30]$, can also be detected in routinely processed BM biopsies. ZAP-70 positivity is more frequently found in cases with diffuse BM infiltration, a pattern previously known to be associated with higher stage and poor prognosis [25]. However, ZAP-70 expression is not limited to B-CLL, but may be found in a variety of other NHL [31-33].

B-prolymphocytic leukemia is a rare disease characterized by high leukocyte counts, splenomegaly and BM infiltrates by cells with wider cy toplasm and enlarged nuclei with prominent nucleoli. It usually lacks CD5 expression. The precise classification of these cases is currently under discussion. Cases of B-PLL carrying a $t(11 ; 14)$ as described in the older literature will currently be regarded as leukemic MCL by most authors [34].

MCL involves the BM in 55-90\% of cases and can show a variety of patterns, including predominantly paratrabecular infiltrates. Demonstration of the characteristic CD5+/CD23-immunophenotype and of cyclin D1 overexpression facilitates the diagnosis [27]. Cyclin D1 expression, especially when investigated with the new monoclonal rabbit antibody (SP-4, DCS, Germany) and complemented by CD20 staining, is very sensitive for the detection of residual disease (fig. 1F). Blastoid and pleomorphic variants of MCL have to be distinguished from lymphoblastic lymphoma/acute leukemia and large cell lymphoma, respectively. Another characteristic feature of MCL is the lack of the CDK inhibitor p27, which is strongly expressed by other small B-cell neoplasms with the exception of HCL [35]. 

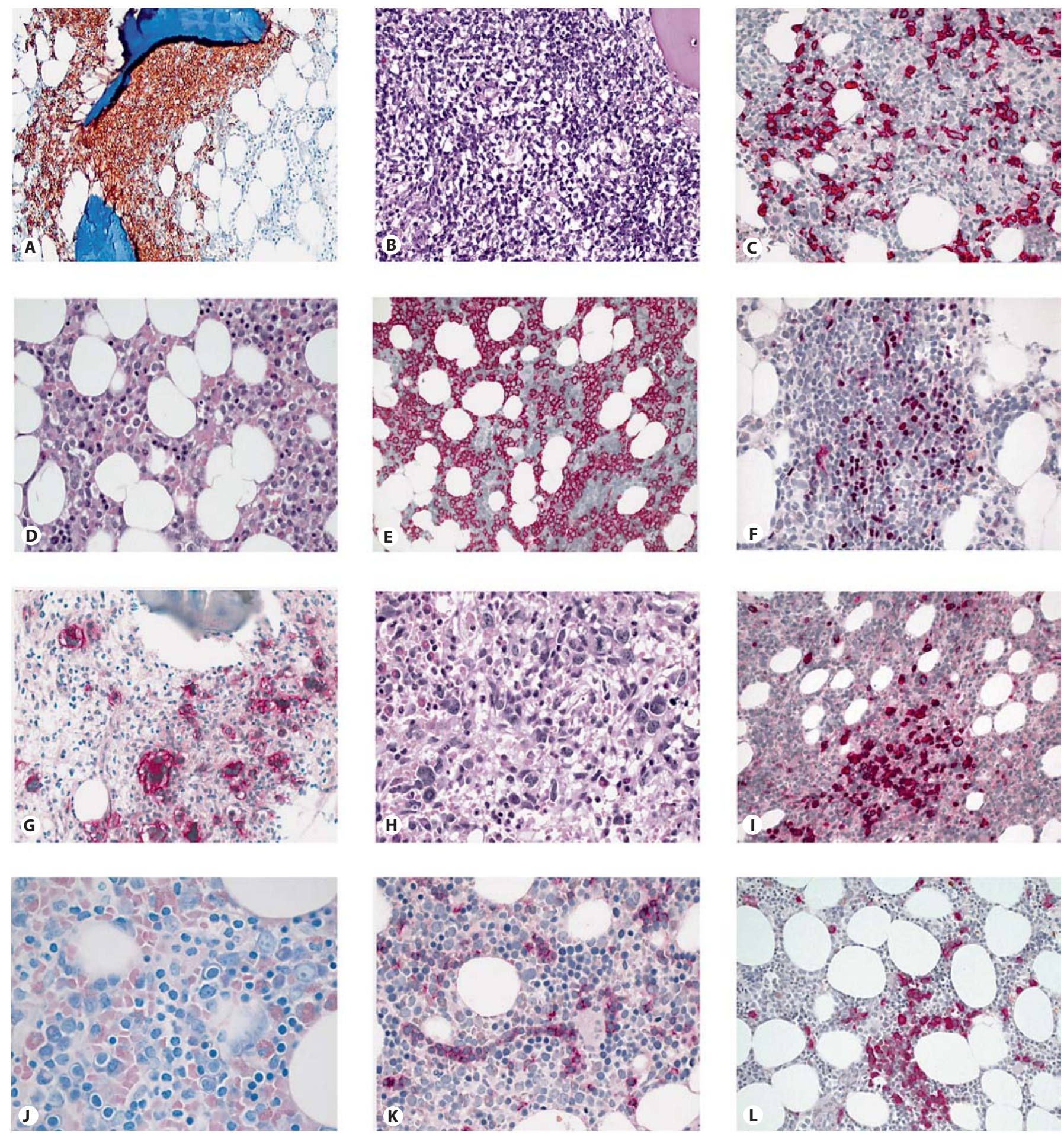

Fig. 1. Patterns of $\mathrm{BM}$ infiltration by malignant lymphoma. A CD20 staining of a characteristic paratrabecular FL infiltrate. Note the characteristic 'wallpaper-like' infiltration pattern. B, C Two microphotographs representing a DLBCL with a 'pseudo-discordant' BM infiltration. In the HE staining (B), a densely packed lymphocytic infiltrate is noticed, with only a few blasts. The CD20 immunostain (C) highlights the scattered blasts within the background of 'reactive' T cells simulating a 'discordant' infiltration. D, E A typical case of HCL with a loose interstitial infiltrate of hairy cells (D). The tumor cells are strongly positive for CD20 (E). F Cyclin D1 staining of a MCL, with a strong immunoreactivity of neoplastic lymphocytes, intermingled with cyclin D1-negative T cells. G CD30-positive Hodgkin and Reed-Sternberg cells in a BM infiltrate of classical HL. H, I A case of a periph- 
FL, especially of lower grades, shows BM involvement in $50-60 \%$ of cases. FL classically shows strictly paratrabecular, rather loose infiltrates accompanied by significant fibrosis (fig. 1A) $[1,4,6]$. True neoplastic follicles are rare, occurring in less than $5 \%$ of cases, and can be distinguished from reactive lymphoid follicles by their bcl-2 positivity [36]. Due to the characteristic distribution of the neoplastic infiltrates, immunohistochemistry is of minor importance in cases with an established diagnosis of FL, but occasionally can detect small linear accumulations of neoplastic B cells lining the bony trabecules [10, 37]. The neoplastic infiltrates in FL usually contain a high number of reactive $\mathrm{T}$ cells, which should not distract from a diagnosis if the typical morphological features are present. Of note, CD10 expression can be absent in BM infiltrates and is difficult to evaluate due to positive staining of other marrow elements. A relatively frequent phenomenon of BM infiltration in FL and also diffuse large B-cell lymphoma (DLBCL) is the presence of predominantly small cell infiltrates in cases with a diagnosis of higher-grade FL or DLBCL at another site. These so-called 'discordant' infiltrates can be evidence of either disease transformation at an extramedullary location, the presence of a second, unrelated lymphoid neoplasm in the $\mathrm{BM}$ or might even be due to the influence of the BM microenvironment [38-40]. True discordant infiltrates need to be discerned from cases of high-grade lymphoma in which the neoplastic large cells are obscured by large numbers of small $\mathrm{T}$ cells, simulating a lymphomatous infiltrate of lower grade. Immunohistochemistry for CD20 and CD3 helps to resolve these cases (fig. 1B, C).

LPL (corresponding to the lymphoplasmacytic immunocytoma of the Kiel classification) is most often encountered in the presence of the clinical syndrome of Waldenström's macroglobulinemia with the presence of an IgM paraprotein and BM involvement [41, 42]. Histologically, the BM shows variably distributed, often interstitial and diffuse infiltrates of small lymphocytes, lymphoplasmacytoid cells and plasma cells with variable fibrosis and a

eral T-cell lymphoma (NOS), with highly pleomorphic tumor cells mimicking Reed-Sternberg or Hodgkin cells on HE (H). The tumor cells strongly express CD3 (I). J, K A case of a T-LGL with a morphologically inconspicuous, predominantly intrasinusoidal infiltrate of CD8-positive (K) T cells. $\mathbf{L}$ Interstitial BM infiltrates of multiple myeloma stained for IgA.

Malignant Lymphoma and Related Entities in the BM Trephine Biopsy characteristic admixture of mast cells. Dutcher bodies may be frequent. Demonstration of cytoplasmic immunoglobulin expression and the frequent, though not obligatory absence of CD5 expression can help to confirm the diagnosis.

Nodal and extranodal marginal zone B-cell lymphomas infiltrate the BM less frequently than other small Bcell NHL, in approximately $10-40 \%$ of cases [43-45], possibly with a higher frequency for nodal MZL [46]. They usually show intertrabecular, nodular infiltrates, which may contain reactive germinal centers. Their phenotype (CD20+, CD10-, CD43-/+, CD5-) with absence of characteristic markers, makes differentiation from reactive nodules and other NHL subtypes difficult. The rare CD5+ extranodal MZL cases seem to show a higher tendency for BM involvement [47].

Splenic marginal zone B-cell lymphoma (SMZL) [20, 48-50], which encompasses splenic lymphoma of villous lymphocytes, shows a much higher frequency of BM infiltration than the other marginal zone B-NHLs. In addition to nodular and interstitial infiltrates, SMZL characteristically shows an intrasinusoidal pattern $[19,21,51]$. In cases of pure intrasinusoidal spread, the infiltrates are very hard to detect by conventional morphology, and CD20 immunohistochemistry is required for suspected cases of SMZL. An important pitfall is persistent polyclonal lymphocytosis with binucleated lymphocytes, a benign lymphoproliferation usually found in female smokers, which can closely simulate the sinusoidal pattern of BM involvement of SMZL [52].

HCL is clinically characterized by splenomegaly, frequent cytopenia with monocytopenia, presence of circulating hairy cells and a dry tap in BM examination. Morphologically, the characteristic infiltrate shows interstitial, in early cases rather inconspicuous aggregates of medium-sized lymphoid cells with clear cytoplasm and oval to bean-shaped nuclei, accompanied by reticulin fibrosis (fig. 1D) [3]. The cells show strong expression of CD20, frequently giving them a 'woolly' or 'hairy' appearance (fig. 1E). In addition, they are usually positive for the monoclonal antibody DBA.44, tartate-resistant acid phosphatase, CD25 (IL-2 receptor) and in the majority of cases for cyclin D1 [35, 53-55]. Hairy cells lack CD5 and CD23. A highly specific new marker for primary diagnosis is annexin-1, which however is not suitable for residual disease detection due to its expression in granulocytes [56]. This unique immunoprofile helps to differentiate HCL from other B-NHL in difficult cases and aids in the detection of minimal residual disease.

Pathobiology 2007;74:133-143 
High-Grade B-Cell NHL

Diffuse large cell B-cell lymphoma has a rather low frequency of BM infiltration, ranging from 10 to $35 \%$ [3]. The patterns of infiltration are highly variable, ranging from subtle, focal infiltrates to a 'packed marrow' with complete replacement of hematopoiesis. As mentioned above, so-called discordant infiltrates in patients with DLBCL at another site consist of small neoplastic cells and carry a better prognosis than concordant (i.e. large cell) BM infiltration [57]. In addition to other lymphoma subtypes such as peripheral T-NHL or pleomorphic MCL, non-lymphoid neoplasms such as acute myeloid leukemia or even carcinomas may mimic DLBCL in the BM, and immunohistochemistry is important for establishing the diagnosis. A special problem is the diagnosis of T-cellrich/histiocyte-rich large B-cell lymphoma (TCRBCL) infiltrating the $\mathrm{BM}$, since it can be confused with Hodgkin's lymphoma $[58,59]$. The CD20+, EMA+, CD30-, CD15- phenotype of the neoplastic large cells helps to separate TCRBCL from classic Hodgkin's lymphoma, but separation from nodular lymphocyte-predominant HL is virtually impossible on the BM trephine. However, the latter involves the $\mathrm{BM}$ rather infrequently, whereas $\mathrm{BM}$ infiltrates are common in TCRBCL. BM involvement by Burkitt lymphoma ranges from scattered interstitial foci hard to identify by morphology alone to complete replacement of normal marrow elements by medium-sized blasts with inconspicuous nucleoli, basophilic cytoplasm in Giemsa stain and sometimes starry sky pattern. Necrosis is frequent [3]. Burkitt lymphoma shows a mature $\mathrm{B}$-cell phenotype with coexpression of CD20, CD10 and BCL-6, but lacks terminal deoxyribonucleotidyl transferase $(\mathrm{TdT})$.

\section{Plasma Cell Disorders}

Multiple myeloma (MM) accounts for approximately $10 \%$ of all hematologic neoplasms. BM infiltration by $\mathrm{MM}$ is highly variable and does not follow a recurrent pattern. In typical cases, diagnosis of MM is straightforward by morphology alone [60]. Grading of MM based on cytological features as well as infiltration volume is of prognostic importance [61]. In addition to neoplastic infiltrates, the presence and extent of bone resorption and remodeling should be noted in the report.

In daily practice, distinction from monoclonal gammopathy of unknown significance (MGUS) and occasionally separation from other neoplasms are the most commonly encountered diagnostic problems. In addition to the percentage of plasma cells (above $10 \%$ are considered suspicious), their localization in sheets or clusters without association with vessels, cy tologic atypia, a clearcut light chain restriction and expression of CD56 are criteria supporting a diagnosis of MM rather than MGUS (fig. 1L). MM usually lacks markers of mature B cells such as CD20, but expresses the plasma cell markers CD138, CD38, VS38c, frequently CD56 and cytoplasmic immunoglobulin [60, 62-64]. This phenotype helps to differentiate MM from B-NHL with plasmacytic differentiation, such as LPL or marginal zone B-cell lymphoma. Of note, the lymphoplasmacytic or small cell variant of MM frequently coexpresses CD20 in addition to plasma cell markers and commonly shows cyclin D1 reactivity due to the presence of a $t(11 ; 14)$ translocation $[7,65,66]$. This MM subtype needs to be distinguished from MCL. In patients without morphologically obvious neoplastic infiltrates, such as in early stage disease or after treatment, immunohistochemistry should be performed on a routine basis, since subtle interstitial infiltrates are easily overlooked, especially in small cell and well-differentiated cases. Anaplastic MM and purely plasmablastic cases need to be differentiated from large cell lymphoma and even non-hematologic neoplasms.

In recent years, the detection of non-random chromosomal abnormalities by interphase fluorescent in situ hybridization (FISH) in large series of MM has given significant insights into the biology of the disease and has provided us with important prognostic markers. Recurrent chromosomal translocations involving the immunoglobulin heavy chain locus at 14q32 and numerical aberrations such as deletions of chromosome 13 or hyperdiploid MM allow stratification into groups with widely differing survival and clinical features [67-69]. Interphase FISH can also be applied successfully to BM trephines, thus allowing for the detection of recurrent cytogenetic alterations in MM and other lymphoid neoplasms $[70,71]$.

\section{Peripheral T-Cell Non-Hodgkin's Lymphoma}

Peripheral T-NHL accounts for $<10 \%$ of all NHL in Western countries. The frequency of BM infiltration is strongly dependent on the lymphoma subtype [72-74]. Leukemic and generalized T-NHL including T-cell large granular lymphocyte leukemia (T-LGL), T-cell prolymphocytic leukemia (T-PLL) and hepatosplenic T-cell lymphoma involve the BM in virtually all cases, but the infiltrate is frequently subtle and difficult to recognize by morphology. T-LGL, a relatively common, indolent disorder characterized by peripheral cytopenias, spleno- 
megaly and features of immune dysregulation, is characterized by a interstitial and intrasinusoidal spread of CD3+, usually CD8+ T cells with expression of cytotoxic granule proteins TIA-1 and granzyme B (fig. 1J, K) [75]. Of note, the BM in T-LGL may contain reactive lymphoid nodules which contain a mixture of $B$ cells as well as CD4+ and CD8+ T cells, a potential source of confusion. In contrast to T-LGL, T-PLL commonly shows a marked diffuse, less frequently nodular infiltrate with replacement of hematopoiesis and fat cells. In most cases of TPLL, the neoplastic cells express CD4, together with other mature T-cell markers. Hepatosplenic T-cell lymphoma, an aggressive disease with poor prognosis, is frequently negative for CD4, CD5 and CD8 and perforin, but often expresses CD56 and is TIA-1-positive [76].

Nodal (systemic) anaplastic large cell lymphoma shows overt BM involvement in approximately $10 \%$ of cases, but is detected in about $30 \%$ of cases studied by immunohistochemistry [77]. Immunostains for CD30 or the ALK-1 protein, which is expressed in 70-90\% of cases depending on age group, highlight singly dispersed neoplastic cells in the marrow.

Peripheral T-NHL, NOS shows great cytological and immunophenotypical variability. BM infiltration is relatively common and usually characterized by irregular, nodular infiltrates with a high content of reactive cells, making immunophenotypical characterization of the infiltrate difficult (fig. 1H, I) [72-74]. Angioimmunoblastic T-NHL (AITL) infiltrates the BM in the majority of cases and shows similar diagnostic features as in lymph node biopsies. Of note, $\mathrm{CD} 10$ reactivity, a characteristic feature of AITL, is often absent in the BM [78]. The presence of large, transformed, EBV-positive B cells in the infiltrate may point to a diagnosis of AITL, but can also lead to confusion with T-cell-rich large B-cell lymphoma or Hodgkin's disease. BM involvement is of less importance in the extranodal cytotoxic T-NHL and rare in cutaneous T-cell lymphomas including mycosis fungoides. An important paraneoplastic change accompanying some cases of peripheral T-NHL, mainly of cytotoxic origin, is hemophagocytic syndrome [79]. This syndrome frequently shows a dramatic clinical presentation with fever, cytopenia and hepatosplenomegaly, and may also be found in association with viral and bacterial infections. The BM shows a reduction of hematopoietic elements, variable fibrosis and pronounced infiltrates of histiocytes with ingestion of red cells and other hematopoietic elements [3].

Acute lymphoblastic leukemia/lymphoblastic lymphoma of both B- and T-cell origin is usually character- ized by a massive, diffuse infiltrate of monomorphic blasts with strongly reduced hematopoiesis. The neoplastic cells are monomorphous to moderately pleomorphic, with fine chromatin and small to medium-sized nucleoli. Immunohistochemistry for TdT, which is usually strongly positive in the nuclei of the blasts, CD10, CD79a, Pax-5 and T-cell markers helps to determine the cell lineage and to discriminate it from other neoplasms, mainly AML [80]. Of note, aberrant cross-lineage expression of B, T or myeloid antigens is relatively frequent in acute leukemias, as is positivity for $\mathrm{CD} 34$, and some cases may not be resolved satisfactorily by paraffin section immunophenotyping. For example, expression of B-cell markers Pax-5 or CD79a can be observed in subsets of AML [81, 82]. CD99 (MIC2) expression is common in ALL/LBL and may lead to confusion with other small blue round cell tumors, such as Ewing's sarcoma [83].

\section{Differential Diagnosis of Reactive Lymphoid Infiltrates}

A common diagnostic problem in BM trephines is the distinction of reactive nodular lymphoid infiltrates from nodular infiltrates of low-grade lymphoma $[1,3,4,6,84$, 85]. These reactive infiltrates can be found in a variety of disorders, including autoimmune disease, infections, and chronic myeloproliferative syndromes. A more mixed cellular composition, well-defined borders, intertrabecular location, low number of infiltrates and absence of reticulin fibrosis are morphological features found more often in benign lymphoid nodules [84]. Germinal centers are relatively rare also in benign infiltrates. Immunophenotyping usually shows a predominance of $\mathrm{T}$ cells and a lack of an aberrant marker profile or immunoglobulin light chain restriction. Nevertheless, some cases may remain unresolved with standard diagnostic procedures and may require additional molecular studies (see below).

\section{Interpretation of BM Trephines Post-Therapy}

Description of the vast array of changes which can be encountered after chemotherapy is beyond the scope of this review, but some more common problems in followup biopsies of patients treated for malignant lymphoma are discussed below. The detection of minimal residual disease is easier for lymphoid neoplasms with a well-defined immunophenotype and/or morphology, such as anaplastic large T-cell lymphoma, HCL or MCL, than for predominantly small cell NHL lacking such features. For 
some diseases such as HCL, criteria for defining remission by histological and immunohistochemical staining of BM trephines have been defined [86]. In treated acute lymphoblastic leukemia, combination of topography and immunophenotype helps to discern regenerating benign hematogones, immature B-cell precursors, from residual leukemic blasts, since the presence of small clusters of CD34- or TdT-positive cells is predictive of impending relapse $[87,88]$.

A common problem is the presence of residual nodular lymphoid infiltrates after therapy for small B-cell lymphoma. The determination of their benign or malignant nature frequently requires immunohistochemical examination. Residual nodules may consist entirely of reactive $\mathrm{T}$ cells, thus allowing a diagnosis of complete remission despite morphological features suggestive of persistent disease. In patients having received rituximab (anti-CD20 antibody) therapy, CD79a or CD22 should be included in the diagnostic panel, because downregulation of CD20 expression by the lymphoma cells may lead to a false-negative diagnosis $[89,90]$.

\section{Role of Molecular Examination}

Molecular examination of BM trephines plays only a minor role in routine diagnostic examination. Diagnostic molecular studies are usually performed on lymph node biopsies or on BM aspirates rather than trephines for reasons of easier handling and better DNA or RNA quality obtainable from fresh rather than fixed an decalcified BM samples. Molecular detection of minimal residual disease in NHL patients usually is also performed on aspirates, although the role of potential sampling error due to lesional fibrosis has to be seen critically.

Nevertheless, several groups have shown the feasibility of both DNA- and RNA-based molecular examinations of fixed and decalcified, paraffin-embedded BM trephines [reviewed in 91]. Assessment of B- or T-cell clonality is the most frequent indication for molecular studies [92-94]. In addition to the discrimination of benign and malignant lymphoid infiltrates, determination of the clonal relationship of medullary infiltrates with lymphoma at another site may help to resolve cases of discordant small cell infiltrates in patients with large cell lymphoma mentioned above [39]. Microdissection of lymphoid nodules can help to increase the sensitivity of PCR-based determination of clonality, but requires careful interpretation of results [85]. Since fixation and decalcification decreases the quality of nucleic acids and can lead to false-positive results due to preferential amplification of rare templates, rigorous quality controls and performance of diagnostic PCR assays in duplicate are mandatory. In addition to clonality determination, a range of applications for DNA- as well as RNA-based molecular studies have been described for diagnosis of lymphoma in BM trephines $[91,95,96]$.

\section{References}

1 Brunning R, McKenna R: Bone marrow lymphomas; in Brunning R, McKenna RW (eds): Tumors of the Bone Marrow, Atlas of Tumor Pathology, Third Series. Washington, Armed Forces Institute of Pathology, 1994, pp 369408.

2 Bain BJ: Bone marrow trephine biopsy. J Clin Pathol 2001;54:737-742.

3 Foucar K: Bone Marrow Pathology. Chicago, ASCP Press, 2001.

4 Schmid C, Isaacson PG: Bone marrow trephine biopsy in lymphoproliferative disease. J Clin Pathol 1992;45:745-750.

5 Crotty PL, Smith BR, Tallini G: Morphologic, immunophenotypic, and molecular evaluation of bone marrow involvement in nonHodgkin's lymphoma. Diagn Mol Pathol 1998;7:90-95.

-6 Henrique R, Achten R, Maes B, Verhoef G, De Wolf-Peeters C: Guidelines for subtyping small B-cell lymphomas in bone marrow biopsies. Virchows Arch 1999;435:549-558.
7 Kremer M, Quintanilla-Martinez L, Nahrig J, von Schilling C, Fend F: Immunohistochemistry in bone marrow pathology: a useful adjunct for morphologic diagnosis. Virchows Arch 2005;447:920-937.

8 Hanson CA, Kurtin PJ, Katzmann JA, Hoyer JD, Li CY, Hodnefield JM, Meyers CH, Habermann TM, Witzig TE: Immunophenotypic analysis of peripheral blood and bone marrow in the staging of B-cell malignant lymphoma. Blood 1999;94:3889-3896.

-9 Perea G, Altes A, Bellido M, Aventin A, Bordes R, Ayats R, Remacha AF, Espinosa I, Briones J, Sierra J, Nomdedeu JF: Clinical utility of bone marrow flow cytometry in Bcell non-Hodgkin lymphomas. Histopathology 2004;45:268-274.

10 Schmidt B, Kremer M, Gotze K, John K, Peschel C, Hofler H, Fend F: Bone marrow involvement in follicular lymphoma: comparison of histology and flow cytometry as staging procedures. Leuk Lymphoma 2006; 47:1857-1862.
-11 Campbell JK, Matthews JP, Seymour JF, Wolf MM, Juneja SK: Optimum trephine length in the assessment of bone marrow involvement in patients with diffuse large cell lymphoma. Ann Oncol 2003;14:273-276.

12 Cheson BD, Horning SJ, Coiffier B, Shipp MA, Fisher RI, Connors JM, Lister TA, Vose J, Grillo-Lopez A, Hagenbeek A, Cabanillas F, Klippensten D, Hiddemann W, Castellino R, Harris NL, Armitage JO, Carter W, Hoppe R, Canellos GP: Report of an international workshop to standardize response criteria for non-Hodgkin's lymphomas. NCI Sponsored International Working Group. J Clin Oncol 1999;17:1244.

-13 Buhr T, Laenger F, Schlué J, von Wasielewski R, Lehmann U, Braumann D, Kreipe H: Reliability of lymphoma classification in bone marrow trephines. Br J Haematol 2002;118: 470-476. 
-14 Howell SJ, Grey M, Chang J, Morgenstern GR, Cowan RA, Deakin DP, Radford JA: The value of bone marrow examination in the staging of Hodgkin's lymphoma: a review of 955 cases seen in a regional cancer centre. $\mathrm{Br}$ J Haematol 2002;119:408-411.

- 15 Munker R, Hasenclever D, Brosteanu O, Hiller E, Diehl V: Bone marrow involvement in Hodgkin's disease: an analysis of 135 consecutive cases. German Hodgkin's lymphoma study group. J Clin Oncol 1995;13:403409.

-16 Pangalis GA, Roussou PA, Kittas C, Kokkinou S, Fessas P: B-chronic lymphocytic leukemia. Prognostic implication of bone marrow histology in 120 patients experience from a single hematology unit. Cancer 1987; 59:767-771.

$\checkmark 17$ Rozman C, Montserrat E, Rodriguez-Fernandez JM, Ayats R, Vallespi T, Parody R, Rios A, Prados D, Morey M, Gomis F, et al: Bone marrow histologic pattern - the best single prognostic parameter in chronic lymphocytic leukemia: a multivariate survival analysis of 329 cases. Blood 1984;64:642648.

- 18 Mauro FR, De Rossi G, Burgio VL, Caruso R, Giannarelli D, Monarca B, Romani C, Baroni CD, Mandelli F: Prognostic value of bone marrow histology in chronic lymphocytic leukemia. A study of 335 untreated cases from a single institution. Haematologica 1994;79:334-341.

19 Franco V, Florena AM, Campesi G: Intrasinusoidal bone marrow infiltration: a possible hallmark of splenic lymphoma. Histopathology 1996;29:571-575.

20 Franco V, Florena AM, Iannitto E: Splenic marginal zone lymphoma. Blood 2003;101: 2464-2472.

-21 Labouyrie E, Marit G, Vial JP, Lacombe F, Fialon P, Bernard P, de Mascarel A, Merlio JP: Intrasinusoidal bone marrow involvement by splenic lymphoma with villous lymphocytes: a helpful immunohistologic feature. Mod Pathol 1997; 10:1015-1020.

$\checkmark 22$ Levine AM: HIV-associated Hodgkin's disease. Biologic and clinical aspects. Hematol Oncol Clin North Am 1996;10:1135-1148.

23 Levy R, Colonna P, Tourani JM, Gastaut JA, Brice P, Raphael M, Taillan B, Andrieu JM: Human immunodeficiency virus associated Hodgkin's disease: report of 45 cases from the French Registry of HIV-Associated Tumors. Leuk Lymphoma 1995;16:451-456.

-24 Karcher DS: Clinically unsuspected Hodgkin disease presenting initially in the bone marrow of patients infected with the human immunodeficiency virus. Cancer 1993;71: 1235-1238.
25 Schade U, Bock O, Vornhusen S, Jager A, Busche G, Lehmann U, Kreipe H: Bone marrow infiltration pattern in B-cell chronic lymphocytic leukemia is related to immunoglobulin heavy-chain variable region mutation status and expression of $70-\mathrm{kDa}$ zetaassociated protein (ZAP-70). Hum Pathol 2006;37:1153-1161.

26 Kumar S, Green GA, Teruya-Feldstein J, Raffeld M, Jaffe ES: Use of CD23 (BU38) on paraffin sections in the diagnosis of small lymphocytic lymphoma and mantle cell lymphoma. Mod Pathol 1996;9:925-929.

27 Vasef MA, Medeiros LJ, Koo C, McCourty A, Brynes RK: Cyclin D1 immunohistochemical staining is useful in distinguishing mantle cell lymphoma from other low-grade Bcell neoplasms in bone marrow. Am J Clin Pathol 1997;108:302-307.

28 Perz J, Topaly J, Fruehauf S, Hensel M, Ho AD: Level of CD 20-expression and efficacy of rituximab treatment in patients with resistant or relapsing B-cell prolymphocytic leukemia and B-cell chronic lymphocytic leukemia. Leuk Lymphoma 2002;43:149151.

29 Crespo M, Bosch F, Villamor N, Bellosillo B, Colomer D, Rozman M, Marce S, LopezGuillermo A, Campo E, Montserrat E: ZAP70 expression as a surrogate for immunoglobulin-variable-region mutations in chronic lymphocytic leukemia. N Engl J Med 2003;348:1764-1775.

30 Wiestner A, Rosenwald A, Barry TS, Wright G, Davis RE, Henrickson SE, Zhao H, Ibbotson RE, Orchard JA, Davis Z, Stetler-Stevenson M, Raffeld M, Arthur DC, Marti GE, Wilson WH, Hamblin TJ, Oscier DG, Staudt LM: ZAP-70 expression identifies a chronic lymphocytic leukemia subtype with unmutated immunoglobulin genes, inferior clinical outcome, and distinct gene expression profile. Blood 2003;101:4944-4951.

31 Carreras J, Villamor N, Colomo L, Moreno C, Ramon y Cajal S, Crespo M, Tort F, Bosch F, Lopez-Guillermo A, Colomer D, Montserrat E, Campo E: Immunohistochemical analysis of ZAP-70 expression in B-cell lymphoid neoplasms. J Pathol 2005;205:507513.

32 Sup SJ, Domiati-Saad R, Kelley TW, Steinle R, Zhao X, Hsi ED: ZAP-70 expression in Bcell hematologic malignancy is not limited to CLL/SLL. Am J Clin Pathol 2004;122:582587.

33 Admirand JH, Rassidakis GZ, Abruzzo LV, Valbuena JR, Jones D, Medeiros LJ: Immunohistochemical detection of ZAP-70 in 341 cases of non-Hodgkin and Hodgkin lymphoma. Mod Pathol 2004;17:954-961.

34 Ruchlemer R, Parry-Jones N, Brito-Babapulle V, Attolico I, Wotherspoon AC, Matutes E, Catovsky D: B-prolymphocytic leukaemia with $\mathrm{t}(11 ; 14)$ revisited: a splenomegalic form of mantle cell lymphoma evolving with leukaemia. Br J Haematol 2004;125:330-336.
35 Kremer M, Dirnhofer S, Nickl A, Hoefler H, Quintanilla-Martinez L, Fend F: p27(Kip1) immunostaining for the differential diagnosis of small B-cell neoplasms in trephine bone marrow biopsies. Mod Pathol 2001;14: 1022-1029.

36 Torlakovic E, Torlakovic G, Brunning RD: Follicular pattern of bone marrow involvement by follicular lymphoma. Am J Clin Pathol 2002;118:780-786.

37 West RB, Warnke RA, Natkunam Y: The usefulness of immunohistochemistry in the diagnosis of follicular lymphoma in bone marrow biopsy specimens. Am J Clin Pathol 2002;117:636-643.

38 Hodges GF, Lenhardt TM, Cotelingam JD: Bone marrow involvement in large-cell lymphoma. Prognostic implications of discordant disease. Am J Clin Pathol 1994;101: 305-311.

39 Kremer M, Spitzer M, Mandl-Weber S, Stecker K, Schmidt B, Hofler H, QuintanillaMartinez L, Fend F: Discordant bone marrow involvement in diffuse large B-cell lymphoma: comparative molecular analysis reveals a heterogeneous group of disorders. Lab Invest 2003;83:107-114.

40 Robertson LE, Redman JR, Butler JJ, Osborne BM, Velasquez WS, McLaughlin P, Swan F, Rodriguez MA, Hagemeister FB, Fuller LM, et al: Discordant bone marrow involvement in diffuse large-cell lymphoma: a distinct clinical-pathologic entity associated with a continuous risk of relapse. J Clin Oncol 1991;9:236-242.

-41 Lin P, Bueso-Ramos C, Wilson CS, Mansoor A, Medeiros LJ: Waldenström macroglobulinemia involving extramedullary sites: morphologic and immunophenotypic findings in 44 patients. Am J Surg Pathol 2003; 27:1104-1113.

42 Feiner HD, Rizk CC, Finfer MD, Bannan M, Gottesman SR, Chuba JV, Amorosi E: IgM monoclonal gammopathy/Waldenström's macroglobulinemia: a morphological and immunophenotypic study of the bone marrow. Mod Pathol 1990;3:348-356.

43 Kent SA, Variakojis D, Peterson LC: Comparative study of marginal zone lymphoma involving bone marrow. Am J Clin Pathol 2002;117:698-708.

44 Raderer M, Vorbeck F, Formanek M, Osterreicher C, Valencak J, Penz M, Kornek G, Hamilton G, Dragosics B, Chott A: Importance of extensive staging in patients with mucosa-associated lymphoid tissue-type lymphoma. Br J Cancer 2000;83:454-457.

45 Thieblemont C, Berger F, Dumontet C, Moullet I, Bouafia F, Felman P, Salles G, Coiffier B: Mucosa-associated lymphoid tissue lymphoma is a disseminated disease in one third of 158 patients analyzed. Blood 2000;95:802-806. 
-46 Berger F, Felman P, Thieblemont C, Pradier T, Baseggio L, Bryon PA, Salles G, CalletBauchu E, Coiffier B: Non-MALT marginal zone B-cell lymphomas: a description of clinical presentation and outcome in $124 \mathrm{pa}-$ tients. Blood 2000;95:1950-1956.

-47 Ferry JA, Yang WI, Zukerberg LR, Wotherspoon AC, Arnold A, Harris NL: CD5+ extranodal marginal zone B-cell (MALT) lymphoma. A low-grade neoplasm with a propensity for bone marrow involvement and relapse. Am J Clin Pathol 1996;105:3137.

-48 Mollejo M, Menarguez J, Lloret E, Sanchez A, Campo E, Algara P, Cristobal E, Sanchez E, Piris MA: Splenic marginal zone lymphoma: a distinctive type of low-grade B-cell lymphoma. A clinicopathological study of 13 cases. Am J Surg Pathol 1995;19:1146-1157.

-49 Troussard X, Valensi F, Duchayne E, Garand R, Felman P, Tulliez M, Henry-Amar M, Bryon PA, Flandrin G: Splenic lymphoma with villous lymphocytes: clinical presentation, biology and prognostic factors in a series of 100 patients. Groupe Français d'Hématologie Cellulaire (GFHC). Br J Haematol 1996;93: 731-736.

-50 Schmid C, Kirkham N, Diss T, Isaacson PG: Splenic marginal zone cell lymphoma. Am J Surg Pathol 1992;16:455-466.

-51 Audouin J, Le Tourneau A, Molina T, Camilleri-Broet S, Adida C, Comperat E, Benattar L, Delmer A, Devidas A, Rio B, Diebold J: Patterns of bone marrow involvement in 58 patients presenting primary splenic marginal zone lymphoma with or without circulating villous lymphocytes. Br J Haematol 2003; 122:404-412.

52 Feugier P, De March AK, Lesesve JF, Monhoven N, Dorvaux V, Braun F, Gregoire MJ, Jonveaux P, Lederlin P, Bene MC, Labouyrie $\mathrm{E}$ : Intravascular bone marrow accumulation in persistent polyclonal lymphocytosis: a misleading feature for B-cell neoplasm. Mod Pathol 2004;17:1087-1096.

-53 Hoyer JD, Li CY, Yam LT, Hanson CA, Kurtin PJ: Immunohistochemical demonstration of acid phosphatase isoenzyme 5 (tartrate-resistant) in paraffin sections of hairy cell leukemia and other hematologic disorders. Am J Clin Pathol 1997;108:308-315.

-54 Salomon-Nguyen F, Valensi F, Troussard X, Flandrin G: The value of the monoclonal antibody, DBA.44, in the diagnosis of B-lymphoid disorders. Leuk Res 1996;20:909-913.

- 55 Went PT, Zimpfer A, Pehrs AC, Sabattini E, Pileri SA, Maurer R, Terracciano L, Tzankov A, Sauter G, Dirnhofer S: High specificity of combined TRAP and DBA.44 expression for hairy cell leukemia. Am J Surg Pathol 2005; 29:474-478.

56 Falini B, Tiacci E, Liso A, Basso K, Sabattini E, Pacini R, Foa R, Pulsoni A, Dalla Favera R, Pileri S: Simple diagnostic assay for hairy cell leukaemia by immunocytochemical detection of annexin A1 (ANXA1). Lancet 2004;363:1869-1870.
57 Conlan MG, Bast M, Armitage JO, Weisenburger DD: Bone marrow involvement by non-Hodgkin's lymphoma: the clinical significance of morphologic discordance between the lymph node and bone marrow. $\mathrm{Ne}$ braska Lymphoma Study Group. J Clin Oncol 1990;8:1163-1172.

58 Rudiger T, Ott G, Ott MM, Muller-Deubert SM, Muller-Hermelink HK: Differential diagnosis between classic Hodgkin's lymphoma, T-cell-rich B-cell lymphoma, and paragranuloma by paraffin immunohistochemistry. Am J Surg Pathol 1998;22: 1184-1191

59 Skinnider BF, Connors JM, Gascoyne RD: Bone marrow involvement in T-cell-rich Bcell lymphoma. Am J Clin Pathol 1997;108: 570-578.

60 Grogan TM: Plasma cell myeloma marrow diagnosis including morphologic and phenotypic features. Semin Diagn Pathol 2003; 20:211-225.

61 Bartl R, Frisch B, Fateh-Moghadam A, Kettner G, Jaeger K, Sommerfeld W: Histologic classification and staging of multiple myeloma: a retrospective and prospective study of 674 cases. Am J Clin Pathol 1987;87: 342-355.

62 Ely SA, Knowles DM: Expression of CD56/ neural cell adhesion molecule correlates with the presence of lytic bone lesions in multiple myeloma and distinguishes myeloma from monoclonal gammopathy of undetermined significance and lymphomas with plasmocytoid differentiation. Am J Pathol 2002;160:1293-1299.

63 Wei A, Juneja S: Bone marrow immunohistology of plasma cell neoplasms. J Clin Pathol 2003;56:406-411.

64 Turley H, Jones M, Erber W, Mayne K, de Waele M, Gatter K: VS38: a new monoclonal antibody for detecting plasma cell differentiation in routine sections. J Clin Pathol 1994;47:418-422.

65 Specht K, Haralambieva E, Bink K, Kremer M, Mandl-Weber S, Koch I, Tomer R, Hofler $\mathrm{H}$, Schuuring E, Kluin PM, Fend F, Quintanilla-Martinez L: Different mechanisms of cyclin D1 overexpression in multiple myeloma revealed by fluorescence in situ hybridization and quantitative analysis of mRNA levels. Blood 2004;15:1120-1126.

66 Vasef MA, Medeiros LJ, Yospur LS, Sun NC, McCourty A, Brynes RK: Cyclin D1 protein in multiple myeloma and plasmacytoma: an immunohistochemical study using fixed, paraffin-embedded tissue sections. Mod Pathol 1997;10:927-932.

67 Bergsagel PL, Kuehl WM: Critical roles for immunoglobulin translocations and cyclin $\mathrm{D}$ dysregulation in multiple myeloma. Immunol Rev 2003;194:96-104.

68 Bergsagel PL, Kuehl WM: Molecular pathogenesis and a consequent classification of multiple myeloma. J Clin Oncol 2005;23: 6333-6338.
69 Fonseca R, Barlogie B, Bataille R, Bastard C, Bergsagel PL, Chesi M, Davies FE, Drach J, Greipp PR, Kirsch IR, Kuehl WM, Hernandez JM, Minvielle S, Pilarski LM, Shaughnessy JD Jr, Stewart AK, Avet-Loiseau H: Genetics and cytogenetics of multiple myeloma: a workshop report. Cancer Res 2004;64: 1546-1558.

70 Le Maitre CL, Byers RJ, Liu Yin JA, Hoyland JA, Freemont AJ: Dual colour FISH in paraffin wax-embedded bone trephines for identification of numerical and structural chromosomal abnormalities in acute myeloid leukaemia and myelodysplasia. J Clin Pathol 2001;54:730-733.

71 Miranda RN, Mark HF, Medeiros LJ: Fluorescent in situ hybridization in routinely processed bone marrow aspirate clot and core biopsy sections. Am J Pathol 1994;145: 1309-1314.

72 Dogan A, Morice WG: Bone marrow histopathology in peripheral T-cell lymphomas. Br J Haematol 2004;127:140-154.

73 Caulet S, Delmer A, Audouin J, Le Tourneau A, Bernadou A, Zittoun R, Diebold J: Histopathological study of bone marrow biopsies in 30 cases of T-cell lymphoma with clinical, biological and survival correlations. Hematol Oncol 1990;8:155-168.

74 Gaulard P, Kanavaros P, Farcet JP, Rocha FD, Haioun C, Divine M, Reyes F, Zafrani ES: Bone marrow histologic and immunohistochemical findings in peripheral. T-cell lymphoma: A study of 38 cases. Hum Pathol 1991;22:331-338

75 Morice WG, Kurtin PJ, Tefferi A, Hanson CA: Distinct bone marrow findings in T-cell granular lymphocytic leukemia revealed by paraffin section immunoperoxidase stains for CD8, TIA-1, and granzyme B. Blood 2002;99:268-274.

76 Vega F, Medeiros LJ, Bueso-Ramos C, Jones D, Lai R, Luthra R, Abruzzo LV: Hepatosplenic $\gamma / \delta \mathrm{T}$-cell lymphoma in bone marrow. A sinusoidal neoplasm with blastic cytologic features. Am J Clin Pathol 2001;116: 410-409.

-77 Fraga M, Brousset P, Schlaifer D, Payen C, Robert A, Rubie H, Huguet-Rigal F, Delsol G: Bone marrow involvement in anaplastic large cell lymphoma. Immunohistochemical detection of minimal disease and its prognostic significance. Am J Clin Pathol 1995; 103:82-89.

78 Attygalle AD, Diss TC, Munson P, Isaacson PG, Du MQ, Dogan A: CD10 expression in extranodal dissemination of angioimmunoblastic T-cell lymphoma. Am J Surg Pathol 2004;28:54-61.

79 Falini B, Pileri S, De Solas I, Martelli MF, Mason DY, Delsol G, Gatter KC, Fagioli M: Peripheral T-cell lymphoma associated with hemophagocytic syndrome. Blood 1990;75: 434-444. 
-80 Pileri SA, Ascani S, Milani M, Visani G, Piccioli M, Orcioni GF, Poggi S, Sabattini E, Santini D, Falini B: Acute leukaemia immunophenotyping in bone-marrow routine sections. Br J Haematol 1999;105:394-401.

81 Arber DA, Jenkins KA, Slovak ML: CD79 alpha expression in acute myeloid leukemia. High frequency of expression in acute promyelocytic leukemia. Am J Pathol 1996;149: 1105-1110.

82 Tiacci E, Pileri S, Orleth A, Pacini R, Tabarrini A, Frenguelli F, Liso A, Diverio D, LoCoco F, Falini B: PAX5 expression in acute leukemias: higher B-lineage specificity than CD79a and selective association with $\mathrm{t}(8 ; 21)$-acute myelogenous leukemia. Cancer Res 2004;64:7399-7404.

83 Zhang PJ, Barcos M, Stewart CC, Block AW, Sait S, Brooks JJ: Immunoreactivity of MIC2 (CD99) in acute myelogenous leukemia and related diseases. Mod Pathol 2000;13:452458.

84 Thiele J, Zirbes TK, Kvasnicka HM, Fischer $\mathrm{R}$ : Focal lymphoid aggregates (nodules) in bone marrow biopsies: differentiation between benign hyperplasia and malignant lymphoma - a practical guideline. J Clin Pathol 1999;52:294-300.

-85 Kremer M, Cabras AD, Fend F, Schulz S, Schwarz K, Hoefler H, Werner M: PCR analysis of IgH-gene rearrangements in small lymphoid infiltrates microdissected from sections of paraffin-embedded bone marrow biopsy specimens. Hum Pathol 2000;31:847853.
86 Hakimian D, Tallman MS, Kiley C, Peterson L: Detection of minimal residual disease by immunostaining of bone marrow biopsies after 2-chlorodeoxyadenosine for hairy cell leukemia. Blood 1993;82:1798-1802.

87 Rimsza LM, Larson RS, Winter SS, Foucar K, Chong YY, Garner KW, Leith CP: Benign hematogone-rich lymphoid proliferations can be distinguished from B-lineage acute lymphoblastic leukemia by integration of mor phology, immunophenotype, adhesion molecule expression, and architectural features. Am J Clin Pathol 2000;114:66-75.

88 Rimsza LM, Viswanatha DS, Winter SS, Leith CP, Frost JD, Foucar K: The presence of CD34+ cell clusters predicts impending relapse in children with acute lymphoblastic leukemia receiving maintenance chemotherapy. Am J Clin Pathol 1998;110:313320.

89 Douglas VK, Gordon LI, Goolsby CL, White CA, Peterson LC: Lymphoid aggregates in bone marrow mimic residual lymphoma after rituximab therapy for non-Hodgkin lymphoma. Am J Clin Pathol 1999;112:844853.

90 Seliem RM, Freeman JK, Steingart RH, Hasserjian RP: Immunophenotypic changes and clinical outcome in B-cell lymphomas treated with rituximab. Appl Immunohistochem Mol Morphol 2006;14:18-23.

91 Fend F, Bock O, Kremer M, Specht K, Quintanilla-Martinez L: Ancillary techniques in bone marrow pathology: molecular diagnostics on bone marrow trephine biopsies. Virchows Arch 2005;447:909-919.
92 Braunschweig R, Baur AS, Delacretaz F, Bri$\operatorname{cod} \mathrm{C}$, Benhattar J: Contribution of IgHPCR to the evaluation of B-cell lymphoma involvement in paraffin-embedded bone marrow biopsy specimens. Am J Clin Pathol 2003;119:634-642.

93 Brinckmann R, Kaufmann O, Reinartz B, Dietel M: Specificity of PCR-based clonality analysis of immunoglobulin heavy chain gene rearrangements for the detection of bone marrow involvement by low-grade Bcell lymphomas. J Pathol 2000;190:55-60.

94 Pittaluga S, Tierens A, Dodoo YL, Delabie J, De Wolf-Peeters C: How reliable is histologic examination of bone marrow trephine biopsy specimens for the staging of non-Hodgkin lymphoma? A study of hairy cell leukemia and mantle cell lymphoma involvement of the bone marrow trephine specimen by histologic, immunohistochemical, and polymerase chain reaction techniques. Am J Clin Pathol 1999;111:179-184.

95 Lehmann U, Bock O, Langer F, Kreipe H: Demonstration of light chain restricted clonal B-lymphoid infiltrates in archival bone marrow trephines by quantitative realtime polymerase chain reaction. Am J Pathol 2001;159:2023-2029.

96 Specht K, Kremer M, Muller U, Dirnhofer S, Rosemann M, Hofler H, Quintanilla-Martinez L, Fend F: Identification of cyclin D1 mRNA overexpression in B-cell neoplasias by real-time reverse transcription-PCR of microdissected paraffin sections. Clin Cancer Res 2002;8:2902-2911. 